\title{
Commodity Price Shocks and the Odds on Fiscal Performance: A Structural Vector Autoregression Approach
}

\author{
FRANCIS Y. KUMAH and JOHN M. MATOVU*
}

Unanticipated changes in commodity prices can generate significant movements in fiscal aggregates. This paper seeks to understand the dynamics of these fiscal movements in the context of transitory commodity price shocks, using sample data from four countries of the Commonwealth of Independent States- two oilexporting and two non-oil-exporting commodity-intensive countries. It adopts a structural vector autoregression approach to identify dynamic effects of commodity price shocks on fiscal performance under two broad tax regimes. Stochastic simulations indicate high probabilities of fiscal overperformance in the short term when commodity prices are high. These probabilities deteriorate significantly, however, in the long run after the transitory positive commodity price shock has dissipated, particularly when lax fiscal policy is adopted during the period of the price boom. [JEL C50, E62, E66]

IMF Staff Papers (2007) 54, 91-112. doi:10.1057/palgrave.imfsp.9450001

hanges in commodity prices translate into shifts in fiscal performance. When commodity prices decline-particularly in the case of commodity-intensive countries - output growth rates decline, the external

${ }^{*}$ Francis Y. Kumah is a senior economist with the Middle East and Central Asia Department of the IMF, and John M. Matovu is an economist with the same department. We thank our colleagues Juan Carlos Di Tata, Aasim Husain, Sam Ouliaris, Peter Winglee, Roman Zytek, and an external reviewer for insightful comments that helped enhance the quality of the paper. We are grateful to Malina Savova for commendable research assistance. 
current account balance worsens, and macroeconomic adjustment processes may stall. In the opposite case of commodity price increases, as in the case of the recent hike in the price of petroleum products, commodity exporters gain, and this is reflected in stronger external current account balances, output growth, and fiscal positions - as has recently been the case of most oilexporting countries, including Kazakhstan and Russia.

Fiscal performance in single-commodity-exporting countries-some of which are oil exporters - depends significantly on commodity prices. For agricultural-commodity exporters, a decline in the international prices of their export commodities worsens their terms of trade and external current account balances and reduces tax revenues. The situation may worsen if the decline in the prices of these exports is accompanied by oil price hikes (in the case of nonoil exporters). Where fiscal policy adjusts to the adverse external shock through streamlining of nonessential expenditures, the burden of private sector adjustment is reduced. Without fiscal adjustment, the terms-oftrade shock translates directly into increasing fiscal deficits - resulting in the twin deficits phenomenon.

This paper is focused on two main issues: (1) the extent to which high volatility of commodity prices affects fiscal performance by increasing the probability of underperformance and (2) the effects of the mode of sequencing of tax and expenditure policy decisions on fiscal performance in the context of transitory commodity price shocks. To shed light on these issues, the paper estimates probabilities of exceeding fiscal revenue floors and expenditure and deficit ceilings in the context of commodity price shocks under two broad tax regimes: a passive tax regime (in which tax decisions are taken in advance and independent of expenditure decisions) and an active tax regime (in which expenditure decisions influence tax decisions, as the former precedes the latter). Data from two oil-exporting countries (Kazakhstan and Russia) and two non-oil-exporting commodity-intensive countries (the Kyrgyz Republic and Tajikistan) are used in the analysis. Whereas a composite commodity price index (comprising the price indices for oil and a major export commodity) is used in analyzing the impact of commodity price shocks on the latter group of countries, commodity price shocks in the former group are limited to oil price shocks.

A structural vector autoregression (VAR) approach is used to measure fiscal performance under two broad tax regimes in the context of volatile commodity prices. Estimated impulse-response functions indicate that, for both groups of countries, increases in commodity prices have significant effects on tax collection, expenditures, and the fiscal balance, with the effects on taxes and expenditures being higher on average under the active tax regime than under the passive regime. The latter finding is explained by the implied high tax costs on the private sector under the active tax regime (which yields nontrivially higher tax revenues than the passive regime). Also, the active tax regime introduces more uncertainty into decision making by businesses, because it will presumably require more frequent changes in tax laws or tax administration, especially where fiscal outcomes are highly 
sensitive to commodity price shocks. Further analysis indicates that although the probability of exceeding tax floors is higher under the active tax regime than under the passive regime, the likelihood of exceeding deficit ceilings tends to be higher under the former regime in the long run, as the positive commodity price shock dissipates. This result reflects the likelihood of increasing expenditures under the active tax regime in anticipation of tax revenues in the context of transitorily favorable commodity price shocks. It indicates the need for caution in projecting expenditure paths before finding tax revenue sources (especially when tax revenues are volatile) — as in the case of medium-term fiscal projections aimed at increasing social outlays to meet the United Nations' Millennium Development Goals.

Our findings underscore the role of uncertainty and commodity price volatility in fiscal management. Countries are continually faced with the challenge of absorbing commodity price volatilities without undermining growth. Additionally, a temporary commodity price increase can undermine longer-term fiscal performance if caution is not exercised in spending during the boom periods. Further, active tax policy may require additional financing - the source of which might adversely affect macroeconomic stability — as it yields higher deficits in the long run and increases output volatility.

\section{Commodity Dependence and Vulnerability to Commodity Price Shocks}

\section{Commodity Price Changes and Fiscal Performance}

Commodity price shocks play a significant role in external accounts and fiscal developments of the countries studied. In general, for all four countries, production of commodities accounts for a significant proportion of national output, ranging from an average in 2000-04 of 7 percent in the Kyrgyz Republic to 21 percent in Russia (Table 1). For the oil-exporting countries, Kazakhstan and Russia, fiscal revenues from oil exports remain significant, averaging $22 \frac{1}{2}$ percent during 2000-04 in both countries. At the same time, the recent high world oil prices continue to boost growth in these countries. Reflecting these developments, the overall general government fiscal surplus averaged about 2 percent of gross domestic product (GDP) in Kazakhstan during 2001-04. The country's total fiscal revenues increased to 26 percent of GDP in 2004 from 22 percent in 2000, about a third of which was derived from oil revenues. Russia also derives about a third of its fiscal revenues from taxing oil production and related activities. On the other hand, as the economies of the Kyrgyz Republic and Tajikistan continue to diversify away from single-commodity dependence, the share of revenues from taxing commodities has declined. For example, the contribution of aluminum and cotton taxation to total revenues in Tajikistan has declined significantly to about 9 percent at the end of 2004, from 25 percent in 2000 .

There is a close association between commodity prices and fiscal performance in the oil-exporting and non-oil-exporting commodityintensive countries of our sample (Figure 1). In particular, there is a 
Table 1. Commodity Prices and Fiscal Vulnerability Indicators, 2000-04 (In percent of GDP, unless otherwise indicated)

$2000 \quad 2001 \quad 2002 \quad 2003 \quad 2004 \quad \begin{gathered}\text { Average } \\ (2000-04)\end{gathered}$

\section{Commodity prices}

Aluminum prices

(U.S. dollars per metric ton)

Cotton prices (U.S. cents per pound)

Oil prices (U.S. dollars per barrel)

Gold prices (U.S. dollars per ounce)

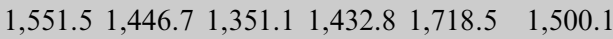

$\begin{array}{rrrrrr}59.0 & 48.0 & 46.3 & 63.4 & 62.0 & 55.8 \\ 28.3 & 24.4 & 25.0 & 28.9 & 38.3 & 29.0 \\ 279.2 & 271.1 & 310.0 & 363.5 & 409.2 & 326.6\end{array}$

\section{Kazakhstan}

Oil and gas production

$\begin{array}{rrrrrr}9.3 & 8.0 & 9.1 & 9.3 & 11.5 & 9.4 \\ 15.3 & 25.8 & 19.5 & 23.5 & 28.7 & 22.5 \\ 46.8 & 48.9 & 50.2 & 53.1 & 55.4 & 50.9 \\ 21.7 & 25.7 & 22.5 & 25.4 & 26.0 & 24.3 \\ 22.5 & 23.0 & 21.0 & 22.5 & 23.3 & 22.5\end{array}$

evenues as percent of total revenues

Oil exports as percent of total exports

Total revenues

Total expenditures

$\begin{array}{rrrrrr}9.0 & 9.0 & 5.2 & 6.8 & 7.1 & 7.4 \\ 2.4 & 1.9 & 2.6 & 4.7 & 5.5 & 3.4 \\ 38.2 & 46.8 & 32.7 & 44.0 & 39.2 & 40.2 \\ 17.6 & 19.5 & 21.7 & 21.7 & 22.3 & 20.6 \\ 28.9 & 26.0 & 28.1 & 27.4 & 27.2 & 27.5\end{array}$

\section{Kyrgyz Republic}

Gold production

Gold revenues as percent of total revenues

Gold exports as percent of total exports

Total revenues before grants

Total expenditures

28.9

$\begin{array}{llllll}25.5 & 20.6 & 20.1 & 19.5 & 20.9 & 21.3 \\ 20.2 & 20.1 & 20.0 & 23.6 & 28.7 & 22.5 \\ 34.5 & 33.4 & 36.9 & 39.5 & 42.8 & 37.4 \\ 15.5 & 15.0 & 15.2 & 14.6 & 14.3 & 14.9 \\ 14.6 & 15.2 & 15.7 & 15.1 & 14.2 & 15.0\end{array}$

\section{Russia}

Oil production

Oil revenues as percent of total revenues

Oil exports as percent of total exports

Total revenues

Total expenditures

$\begin{array}{lrrrrr}\ldots & 16.9 & 17.0 & 16.1 & 15.4 & 16.4 \\ 25.3 & 17.8 & 12.6 & 12.3 & 9.3 & 15.5 \\ & & & & & \\ 65.5 & 71.9 & 75.4 & 78.0 & 80.3 & 74.2 \\ & & & & & \\ 13.6 & 15.2 & 16.7 & 17.3 & 17.9 & 16.1 \\ 19.2 & 18.4 & 19.2 & 19.1 & 20.7 & 19.3\end{array}$

Tajikistan

Aluminum and cotton production

Aluminum and cotton revenues as percent of total revenues

Aluminum and cotton exports as percent of total exports

Total revenues

Total expenditures

Sources: Country authorities; and IMF staff estimates.

generally positive correlation between tax revenues and commodity prices in all four countries, and expenditures also tend to vary directly with these prices. Figure 1 also depicts movements in commodity price indices. For Russia and Kazakhstan, the commodity price index coincides with the oil price index during the period under consideration, whereas for the Kyrgyz Republic and Tajikistan, the commodity price index is a weighted average of the oil price index and the price index of the main export commodity-gold 
Figure 1. Correlations Between Commodity Prices and Fiscal Aggregates
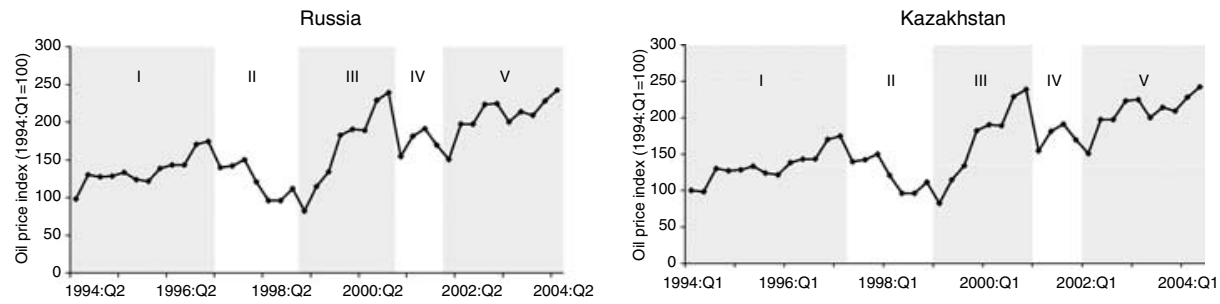

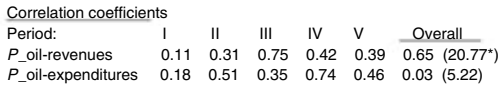
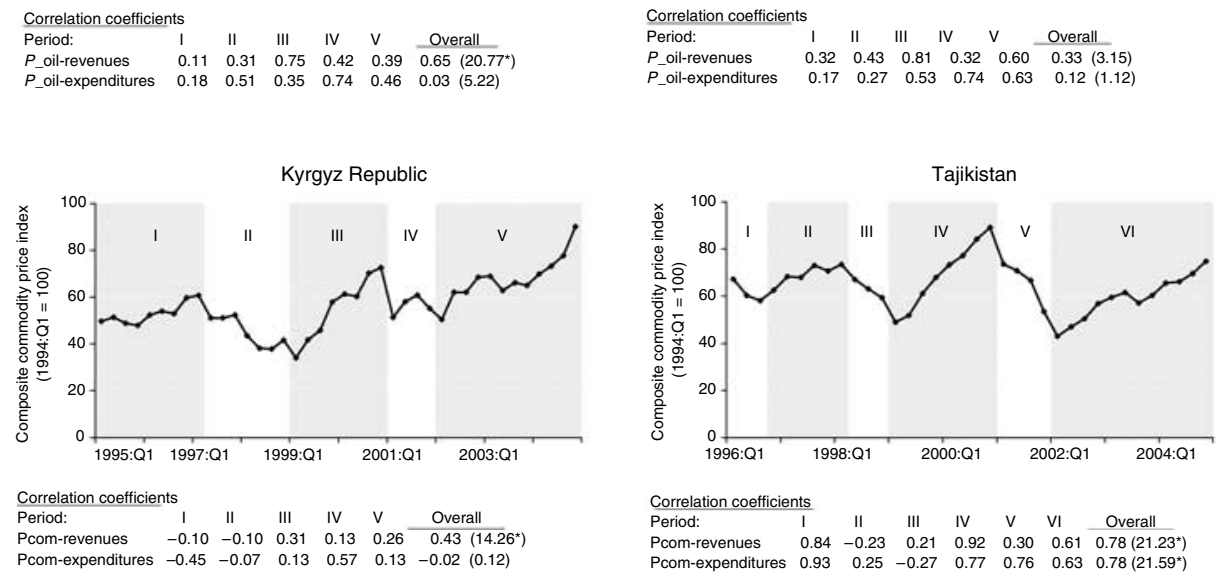

Source: Country authorities; and authors' estimates.

Notes: Alternating shaded and unshaded areas, consecutively labeled from I to VI, depict periods of commodity price increases and decreases, respectively. $P_{-}$oil is the oil price index, and for Tajikistan and the Kyrgyz Republic, Pcom denotes the commodity price index. An asterisk (*) indicates significance of the Ljung-Box $Q$-statistics, indicating rejection of the null of no correlation at the 5 percent significance level.

in the Kyrgyz Republic, and cotton and aluminum in Tajikistan. During the identified episodes of commodity price changes (the shaded portions of Figure 1 indicate periods of rising commodity prices), we observe a positive correlation between these prices and expenditures when prices are increasing, especially in the oil-exporting countries. In some instances, these correlations fall with declining commodity prices - and even become negative, indicating nonreversal of spending patterns during commodity price downturns, precisely because procyclical expenditure retrenchments are generally rare.

Observed variations in fiscal performance are partly influenced by commodity price volatility. International commodity prices (aluminum, cotton, and oil prices) are characterized by strong volatility with periodic persistent upward trends, such as that exhibited by recent world oil price increases. Gold prices have been relatively less volatile over the past two years, but have also seen large swings in the past. The high volatility exhibited by oil prices could be a result of the structure of the market, geopolitical influences, and the high fixed costs involved in exploration and 
production of oil (Engel and Valdés, 2000). For commodity-dependent countries, the high volatility of revenues is sometimes accompanied by procyclical spending patterns that increase fiscal policy uncertainty and reduce growth (Barnett and Ossowski, 2002).

\section{Identifying Fiscal Regimes and Commodity Price Shocks}

Following an investigation of the time series characteristics of the data (see the Appendix for data description and sources, and Kumah and Matovu (2005) for the detailed time series characteristics of the data), an empirical assessment of the effects of commodity price shocks on fiscal performance is carried out within a structural VAR framework. The approach allows for identification of independently distributed and economically meaningful price shocks. In addition, the approach permits a distinction between stochastic automatic feedback effects and discretionary (unanticipated) policy shocks, and estimation of the direct impact of shocks so identified. In particular, the direct impact of commodity price shocks on tax revenues can be distinguished from the effects of discretionary changes in tax policyjust as the automatic stabilizing effects of taxes on output can be isolated from unanticipated output shocks.

As is well known in the empirical literature on monetary policy shocks, proper identification of independent policy shocks depends on appropriate specification of the VAR. The identification of fiscal shocks poses even more challenges because, unlike most monetary policy shocks, fiscal policy changes are often announced well before they are implemented.

To uncover economically meaningful shocks, we follow Blanchard and Perotti (1999) and use a structural VAR specification of the form

$$
\begin{gathered}
{\left[\begin{array}{cccc}
1 & 0 & 0 & 0 \\
0 & 1 & 0 & -\alpha_{24} \\
0 & 0 & 1 & -\alpha_{34} \\
0 & -\alpha_{42} & -\alpha_{43} & 1
\end{array}\right]\left[\begin{array}{c}
u_{t}^{p c o m} \\
u_{t}^{\operatorname{Rev} / y} \\
u_{t}^{E x p / y} \\
u_{t}^{y}
\end{array}\right]} \\
=\left[\begin{array}{cccc}
1 & 0 & 0 & 0 \\
\beta_{21} & 1 & \beta_{23} & 0 \\
\beta_{31} & \beta_{32} & 1 & 0 \\
\beta_{41} & 0 & 0 & 1
\end{array}\right]\left[\begin{array}{c}
v_{t}^{p c o m} \\
v_{t}^{\operatorname{Rev} / y} \\
v_{t}^{E x p / y} \\
v_{t}^{y}
\end{array}\right]
\end{gathered}
$$

using the vector of variables $X_{t}=\left[\ln \operatorname{Pcom}_{t}, \ln \left(\operatorname{Rev}_{t} / y_{t}\right), \ln \left(\operatorname{Exp}_{t} / y_{t}\right), \ln y_{t}\right]^{\prime}$, with the elements representing the logarithms of the commodity price index, revenue/GDP ratio, government spending/GDP ratio, and nominal GDP, 
respectively. ${ }^{1}$ The variable $v_{t}$ is a matrix of economically meaningful structural shocks assumed to be serially uncorrelated with a diagonal contemporaneous covariance matrix, $\Omega$, and $u_{t}$ is a matrix of innovations. The coefficients on the left-hand side capture the working of automatic stabilizers, whereas those on the right-hand side reflect responses to shocksunexpected commodity price shocks $\left(v_{t}^{\text {pcom }}\right)$, discretionary fiscal policy shocks $\left(v_{t}^{R e v / y}\right.$ and $\left.v_{t}^{\text {Exp/y }}\right)$ and output shocks $\left(v_{t}^{y}\right)$. The system depicts contemporaneous relationships between automatic-stabilizing innovations and discretionary policy decisions. It assumes, from the point of view of automatic stabilizers, a time lag between commodity price innovations and changes in revenues, expenditures, and output. Following Fatás and Mihov (2001), Blanchard and Perotti (1999), and Perotti (2002), we assume that government tax and spending decisions do not react contemporaneously to changes in real activity.

To identify the structural shocks, we adopt an approach used by Blanchard and Perotti (1999) to extract the automatic stabilizers from tax and spending innovations. The argument used by Blanchard and Perotti is that using time series at the quarterly frequency ensures that there is no discretionary response of fiscal policy (tax and expenditure changes) to unexpected movements in output within the same period. As a consequence, movements in tax revenues within the same quarter exclude the effects of output shocks and are solely attributed to commodity price shocks, expenditure shocks, and tax policy shocks. For instance, in Equation (1), if there is no response of discretionary tax policy to unexpected movements in expenditures (that is, for $\beta_{23}=0$ ), then movements in taxes are due solely to passive tax policy. Following Blanchard and Perotti, we use prior information on $-\alpha_{24}$ and $-\alpha_{34}$-estimated from the data as output elasticity of tax and expenditures, respectively - in extracting the short-term impact of automatic stabilizers. The new reduced-form tax and expenditure innovations are therefore cyclically adjusted tax revenues and government spending innovations derived as follows:

$$
\begin{aligned}
& \tilde{u}_{t}^{R e v / y}=u_{t}^{R e v / y}-\alpha_{24} u_{t}^{y}, \\
& \tilde{u}_{t}^{E x p / y}=u_{t}^{E x p / y}-\alpha_{34} u_{t}^{y} .
\end{aligned}
$$

\footnotetext{
${ }^{1}$ Our choice of variables to include in the VAR was influenced by the lead provided by Blanchard and Perotti (1999) and our specific interest in sensitivity of fiscal outcomes to commodity price shocks. Nevertheless, we investigated the impact of world interest rate shocks on government finances - the results show insignificant sensitivity of the fiscal stances to world interest rate shocks. This finding may be due to the fact that most debt in these countries - except Russia, perhaps - is contracted on concessional terms with long maturities, and interest payments are generally a small component of total spending.
} 
Combining Equations (1) and (2) and with further manipulations, the structured system can be specified in the form:

$$
\left[\begin{array}{c}
u_{t}^{p c o m} \\
\tilde{u}_{t}^{\text {Rev } / y} \\
\tilde{u}_{t}^{\text {Exp } / y} \\
u_{t}^{y}
\end{array}\right]=\left[\begin{array}{cccc}
1 & 0 & 0 & 0 \\
\alpha & 1 & \beta & 0 \\
\gamma & \chi & 1 & 0 \\
\theta_{1} & \theta_{2} & \theta_{3} & 1
\end{array}\right]\left[\begin{array}{c}
v_{t}^{p c o m} \\
v_{t}^{\text {Rev } / y} \\
v_{t}^{E x p / y} \\
v_{t}^{y}
\end{array}\right] .
$$

It is easy to show, using Equations (1)-(3), that

$$
\begin{aligned}
\alpha & =\beta_{21}, \beta=\beta_{23}, \gamma=\beta_{31}, \chi=\beta_{32}, \theta_{1}=\alpha_{42}+\alpha_{43} \beta_{21}+\alpha_{43} \beta_{31}, \\
\theta_{2} & =\alpha_{42}+\alpha_{43} \beta_{32}, \text { and } \theta_{3}=\alpha_{42} \beta_{23}+\alpha_{43}
\end{aligned}
$$

The coefficients in the final form of the system as represented in Equation (3) can be interpreted as follows:

- Commodity price shocks are strictly exogenous.

- $\alpha$ indicates the response of government revenues to unanticipated commodity price shocks, whereas $\beta$ measures the response of revenues to discretionary expenditure decisions.

- Government expenditures respond to commodity price and revenue shocks - the strengths of the responses are indicated by the coefficients $\gamma$ and $\chi$, respectively.

- Cyclically adjusted revenues and expenditures do not respond to unanticipated output shocks within the same quarter, simply because the cyclical components of these revenues and expenditures have been extracted away using the filters indicated in Equation (2).

- Output responds contemporaneously to unanticipated commodity price shocks and discretionary revenue and expenditure policy shocks-the magnitudes of the responses are given by $\theta_{1}, \theta_{2}$, and $\theta_{3}$, respectively. Discretionary revenue and expenditure decisions affect output only indirectly through the autonomous relationship between output, revenues, and expenditures as indicated in Equation (1) - in fact, $\theta_{2}$ and $\theta_{3}$ are functions of the autonomous responses of output to revenues and expenditures $\left(\alpha_{42}\right.$ and $\alpha_{43}$, respectively), the response of revenues to discretionary expenditure shocks $(\beta)$, and the response of expenditures to discretionary revenue shocks $(\chi)$, with $\theta_{2}=\alpha_{42}+\alpha_{43} \chi$ and $\theta_{3}=\alpha_{42} \beta_{+} \alpha_{43}$.

Without further restrictions, the system represented in Equation (3) is unidentified. We adopt two broad characterizations of tax regimes to help identify the economically meaningful shocks as follows:

(1) Passive tax regime: This regime is characterized by weak exogeneity of government spending decisions on tax revenues $(\beta=0)$. Two versions of this model are estimated. The first version assumes immediate impact of tax and spending decisions on output (Model I: $\beta=0$, an exactly 
identified model). Under the second version, tax decisions affect output only with a lag (Model II: $\beta=0$ and $\theta_{2}=0$, an overidentified model).

(2) Active tax regime: Under this regime, expenditure decisions are taken without any contemporaneous feedback or considerations for tax performance (that is, where $\chi=0$ ), whereas tax decisions accommodate expenditure plans. Just as under the passive tax regime, we consider two alternative situations-immediate effect of tax and expenditure decisions on output (Model III: $\chi=0$, an exactly identified model), and the absence of a contemporaneous tax effect on output (Model IV: $\chi=0$ and $\theta_{2}=0$, an overidentified model).

In terms of political economy, the passive tax regime implies that tax decisions are made prior to and independent of expenditure decisions, whereas the active tax regime assumes subordination of tax decisions to spending programs.

\section{Empirical Results}

\section{Effects of Commodity Price Shocks}

\section{Contemporaneous effects of shocks}

Table 2 presents estimates of contemporaneous effects of commodity price shocks on innovations in fiscal aggregates under alternative fiscal regimes. It indicates (1) the magnitude and significance of the impact of commodity price shocks on tax innovations, (2) the varying impact and significance of expenditure shocks on tax innovations, and (3) the importance of commodity price shocks and discretionary fiscal policy shocks on output. It also presents information on the statistical credibility of the differentiation within each broad fiscal regime-in short, the significance of the overidentifying restrictions.

The results indicate a generally significant positive impact of commodity price shocks on revenue/GDP innovations $(\alpha)$. In addition, expenditure/GDP innovations increase in response to commodity price shocks and discretionary tax policy shocks. In all the countries, except Kazakhstan, we find positive and significant responses of revenue/GDP innovations to commodity price shocks. Even in the case of Kazakhstan, the estimates have the correct signs, although they are not statistically significant. Further, these results are largely independent of fiscal regimes, except in Tajikistan where the responses differ significantly between fiscal regimes - they jump from about 0.7 under the passive tax regime to 3.0 under the active tax regime. The estimated contemporaneous impact of commodity price shocks on revenue/ GDP innovations is particularly strong for Russia, where a 1 percent increase in commodity prices results in an estimated 0.9 percent increase in revenue/ GDP innovations - reflecting the high oil intensity of the Russian economy, with oil production contributing slightly more than one-fifth of total revenues in 2000-04 (Table 1). For the Kyrgyz Republic, the estimated responses are about 0.5 under both tax regimes. This seeming invariance of the response of 


\begin{tabular}{|c|c|c|c|c|c|c|c|c|c|}
\hline \multirow{3}{*}{$\begin{array}{l}\text { Panel 1: Kyrgyz Republic } \\
\text { Parameters }\end{array}$} & \multicolumn{4}{|c|}{$(1995: Q 1-2004: Q 4$, number of lags =4) } & \multirow{3}{*}{$\begin{array}{l}\text { Panel 2: Tajikistan } \\
\text { Parameters }\end{array}$} & \multicolumn{4}{|c|}{$(1996: Q 1-2004: Q 4$, number of lags $=3$ ) } \\
\hline & \multicolumn{2}{|c|}{ Passive tax regime } & \multicolumn{2}{|c|}{ Active tax regime } & & \multicolumn{2}{|c|}{ Passive tax regime } & \multicolumn{2}{|c|}{ Active tax regime } \\
\hline & $\begin{array}{l}\text { Model } \\
\text { I }\end{array}$ & $\begin{array}{l}\text { Model } \\
\text { II }\end{array}$ & $\begin{array}{l}\text { Model } \\
\text { III }\end{array}$ & $\begin{array}{l}\text { Model } \\
\text { IV }\end{array}$ & & $\begin{array}{l}\text { Model } \\
\text { I }\end{array}$ & $\begin{array}{l}\text { Model } \\
\text { II }\end{array}$ & $\begin{array}{l}\text { Model } \\
\text { III }\end{array}$ & $\begin{array}{c}\text { Model } \\
\text { IV }\end{array}$ \\
\hline$\alpha$ & $\begin{array}{c}0.444 \\
(0.182)\end{array}$ & $\begin{array}{c}0.444 \\
(0.182)\end{array}$ & $\begin{array}{c}0.467 \\
(0.191)\end{array}$ & $\begin{array}{c}0.467 \\
(0.193)\end{array}$ & $\alpha$ & $\begin{array}{c}0.675 \\
(0.207)\end{array}$ & $\begin{array}{c}0.637 \\
(0.203)\end{array}$ & $\begin{array}{c}3.018 \\
(0.963)\end{array}$ & $\begin{array}{c}3.018 \\
(0.963)\end{array}$ \\
\hline$\beta$ & & & $\begin{array}{c}0.333 \\
(0.176)\end{array}$ & $\begin{array}{c}0.333 \\
(0.176)\end{array}$ & $\beta$ & & & $\begin{array}{c}4.631 \\
(0.813)\end{array}$ & $\begin{array}{c}4.631 \\
(0.813)\end{array}$ \\
\hline$\gamma$ & $\begin{array}{c}0.573 \\
(0.199)\end{array}$ & $\begin{array}{c}0.573 \\
(0.191)\end{array}$ & $\begin{array}{c}0.543 \\
(0.197)\end{array}$ & $\begin{array}{c}0.543 \\
(0.190)\end{array}$ & $\gamma$ & $\begin{array}{c}1.868 \\
(0.696)\end{array}$ & $\begin{array}{c}0.682 \\
(0.214)\end{array}$ & $\begin{array}{c}0.530 \\
(0.194)\end{array}$ & $\begin{array}{c}0.530 \\
(0.194)\end{array}$ \\
\hline$\chi$ & $\begin{array}{c}0.333 \\
(0.176)\end{array}$ & $\begin{array}{c}0.347 \\
(0.176)\end{array}$ & & & $\chi$ & $\begin{array}{c}3.460 \\
(0.618)\end{array}$ & $\begin{array}{c}0.296 \\
(0.052)\end{array}$ & & \\
\hline$\theta_{1}$ & $\begin{array}{c}0.430 \\
(0.184)\end{array}$ & $\begin{array}{c}0.406 \\
(0.180)\end{array}$ & $\begin{array}{c}0.430 \\
(0.184)\end{array}$ & $\begin{array}{c}0.423 \\
(0.180)\end{array}$ & $\theta_{1}$ & $\begin{array}{l}-5.894 \\
(2.166)\end{array}$ & $\begin{array}{l}-6.915 \\
(2.560)\end{array}$ & $\begin{array}{l}-7.179 \\
(2.656)\end{array}$ & $\begin{array}{l}-6.216 \\
(2.301)\end{array}$ \\
\hline$\theta_{2}$ & $\begin{array}{l}-0.158 \\
(0.169)\end{array}$ & & $\begin{array}{l}-0.177 \\
(0.169)\end{array}$ & & $\theta_{2}$ & $\begin{array}{c}-10.692 \\
(1.916)\end{array}$ & & $\begin{array}{c}0.578 \\
(0.198)\end{array}$ & \\
\hline$\theta_{3}$ & $\begin{array}{c}0.087 \\
(0.167)\end{array}$ & $\begin{array}{c}0.088 \\
(0.167)\end{array}$ & $\begin{array}{c}0.033 \\
(0.169)\end{array}$ & $\begin{array}{c}0.032 \\
(0.167)\end{array}$ & $\theta_{3}$ & $\begin{array}{l}-3.083 \\
(0.556)\end{array}$ & $\begin{array}{l}-13.191 \\
(2.269)\end{array}$ & $\begin{array}{l}-13.684 \\
(2.355)\end{array}$ & $\begin{array}{c}-11.849 \\
(2.039)\end{array}$ \\
\hline $\begin{array}{l}\text { Likelihood ratio test for } \\
\text { overidentification }\end{array}$ & & & & & $\begin{array}{l}\text { Likelihood ratio test for } \\
\text { overidentification }\end{array}$ & & & & \\
\hline$\chi^{2}(1)$ & & 0.876 & & 1.750 & $\chi^{2}(1)$ & & 91.136 & & 9.791 \\
\hline Significance level & & 0.349 & & 0.186 & Significance level & & 0.000 & & 0.000 \\
\hline
\end{tabular}


Table 2 (concluded)

\begin{tabular}{|c|c|c|c|c|c|c|c|c|c|}
\hline \multirow{3}{*}{$\begin{array}{l}\text { Panel 3: Kazakhstan } \\
\text { Parameters }\end{array}$} & \multicolumn{4}{|c|}{ (1994:Q1-2004:Q2, number of lags = 3) } & \multirow{3}{*}{$\begin{array}{l}\text { Panel 4: Russia } \\
\text { Parameters }\end{array}$} & \multicolumn{4}{|c|}{$(1994: Q 2-2004: Q 2$, number of lags $=4)$} \\
\hline & \multicolumn{2}{|c|}{ Passive tax regime } & \multicolumn{2}{|c|}{ Active tax regime } & & \multicolumn{2}{|c|}{ Passive tax regime } & \multicolumn{2}{|c|}{ Active tax regime } \\
\hline & $\begin{array}{l}\text { Model } \\
\text { I }\end{array}$ & $\begin{array}{l}\text { Model } \\
\text { II }\end{array}$ & $\begin{array}{l}\text { Model } \\
\text { III }\end{array}$ & $\begin{array}{l}\text { Model } \\
\text { IV }\end{array}$ & & $\begin{array}{l}\text { Model } \\
\text { I }\end{array}$ & $\begin{array}{l}\text { Model } \\
\text { II }\end{array}$ & $\begin{array}{l}\text { Model } \\
\text { III }\end{array}$ & $\begin{array}{l}\text { Model } \\
\text { IV }\end{array}$ \\
\hline$\alpha$ & $\begin{array}{c}0.018 \\
(0.160)\end{array}$ & $\begin{array}{c}0.018 \\
(0.160)\end{array}$ & $\begin{array}{c}0.042 \\
(0.374)\end{array}$ & $\begin{array}{c}0.042 \\
(0.374)\end{array}$ & $\alpha$ & $\begin{array}{c}0.859 \\
(0.226)\end{array}$ & $\begin{array}{c}0.859 \\
(0.226)\end{array}$ & $\begin{array}{c}0.886 \\
(0.233)\end{array}$ & $\begin{array}{c}0.886 \\
(0.233)\end{array}$ \\
\hline$\beta$ & & & $\begin{array}{l}2.1123 \\
(0.374)\end{array}$ & $\begin{array}{c}2.113 \\
(0.374)\end{array}$ & $\beta$ & & & $\begin{array}{c}0.255 \\
(0.177)\end{array}$ & $\begin{array}{c}0.255 \\
(0.177)\end{array}$ \\
\hline$\gamma$ & $\begin{array}{c}0.318 \\
(0.378)\end{array}$ & $\begin{array}{c}0.318 \\
(0.381)\end{array}$ & $\begin{array}{c}0.136 \\
(0.162)\end{array}$ & $\begin{array}{c}0.136 \\
(0.162)\end{array}$ & $\gamma$ & $\begin{array}{c}0.516 \\
(0.198)\end{array}$ & $\begin{array}{c}0.514 \\
(0.195)\end{array}$ & $\begin{array}{c}0.500 \\
(0.192)\end{array}$ & $\begin{array}{c}0.500 \\
(0.192)\end{array}$ \\
\hline$\chi$ & $\begin{array}{l}2.1123 \\
(0.374)\end{array}$ & $\begin{array}{l}2.1323 \\
(0.375)\end{array}$ & & & $\chi$ & $\begin{array}{l}0.2551 \\
(0.177)\end{array}$ & $\begin{array}{c}0.164 \\
(0.167)\end{array}$ & & \\
\hline$\theta_{1}$ & $\begin{array}{c}0.085 \\
(0.168)\end{array}$ & $\begin{array}{c}0.085 \\
(0.167)\end{array}$ & $\begin{array}{c}0.085 \\
(0.168)\end{array}$ & $\begin{array}{c}0.082 \\
(0.161)\end{array}$ & $\theta_{1}$ & $\begin{array}{c}0.400 \\
(0.200)\end{array}$ & $\begin{array}{c}0.381 \\
(0.190)\end{array}$ & $\begin{array}{c}0.400 \\
(0.200)\end{array}$ & $\begin{array}{c}0.386 \\
(0.193)\end{array}$ \\
\hline$\theta_{2}$ & $\begin{array}{l}0.0765 \\
(0.167)\end{array}$ & & $\begin{array}{c}0.2941 \\
(0.1669)\end{array}$ & & $\theta_{2}$ & $\begin{array}{c}-0.3505 \\
(0.188)\end{array}$ & & $\begin{array}{c}-0.2709 \\
(0.178)\end{array}$ & \\
\hline$\theta_{3}$ & $\begin{array}{c}-0.2892 \\
(0.167)\end{array}$ & $\begin{array}{l}-2.899 \\
(0.167)\end{array}$ & $\begin{array}{l}-0.546 \\
(0.167)\end{array}$ & $\begin{array}{c}-0.0524 \\
(0.160)\end{array}$ & $\theta_{3}$ & $\begin{array}{l}-0.278 \\
(0.178)\end{array}$ & $\begin{array}{c}-0.2934 \\
(0.179)\end{array}$ & $\begin{array}{l}-0.356 \\
(0.188)\end{array}$ & $\begin{array}{c}-0.3437 \\
(0.181)\end{array}$ \\
\hline $\begin{array}{l}\text { Likelihood ratio test for } \\
\text { overidentification }\end{array}$ & & & & & $\begin{array}{l}\text { Likelihood ratio test for } \\
\text { overidentification }\end{array}$ & & & & \\
\hline$\chi^{2}(1)$ & & 0.210 & & 3.235 & $\chi^{2}(1)$ & & 3.671 & & 2.407 \\
\hline Significance level & & 0.647 & & 0.072 & Significance level & & 0.055 & & 0.121 \\
\hline
\end{tabular}

Source: Authors' estimates.

Notes: Figures in parentheses are estimated standard errors. The likelihood ratio test for overidentification is derived under the null hypothesis of equality of the two models under each fiscal regime. 
revenue/GDP innovations to commodity price shocks across tax regimes could be due to either of two factors - improper specification of the data generation process or the tax treatment of oil extraction and petroleum trade in practice in the oil-exporting countries and of commodity trade in the nonoil-exporting countries.

Regarding the response of expenditure/GDP innovations, the results indicate a significant and positive contemporaneous effect of commodity price shocks - the estimate of $\gamma$ is significant across tax regimes in all the countries of our sample, except under the passive tax regime in Kazakhstan. The responses are generally invariant to changes in fiscal regimes, and the increase in expenditure/GDP innovations across tax regimes to a 1 percent shock to the commodity price is about 0.5 percent in Russia and the Kyrgyz Republic. For Tajikistan, the response is lower (averaging 0.5 percent) under the active tax regime than under the passive tax regime (averaging 1.3 percent). The response is insignificant and lowest in Kazakhstandiscretionary spending has mainly dominated recent expenditure patterns, probably because the country has only recently started exploiting its natural oil resources. For all the countries, the estimate of $\chi$ indicates a positive response of expenditures to discretionary tax increases.

Estimated within-quarter output responses reveal the following: (1) although positive commodity price shocks tend to increase output in the oilexporting countries and the Kyrgyz Republic, these shocks reduce output significantly in Tajikistan; (2) discretionary revenue shocks generally display characteristic Keynesian-type effects - tax increases reduce output - with the tax multiplier averaging -0.3 in Russia; but (3) output response to expenditure shocks displays mixed results, possibly reflecting inadequate variation in discretionary expenditures after excluding the autonomous expenditure component. The estimated negative effect of commodity price increases on output in Tajikistan is explained perhaps by the high oil intensity of the economy. Similar growth effects for oil-importing countries have been found by earlier studies (see, for example, Jiménez-Rodríguez and Sánchez, 2004). By excluding oil from the price index, we find that commodity price booms tend to be associated with increases in nominal output in the Kyrgyz Republic and Tajikistan. ${ }^{2}$

Except in the case of Tajikistan, the likelihood ratio test for equality between the two models could not reject the null hypothesis at the 5 percent significance level, suggesting that each fiscal regime could be represented by one model. Thus, in what follows, we limit our discussions to Model I (representing the passive tax regime) and Model III (representing the active tax regime). This means that, although we accept equality of models within tax regimes, we leave the significance of the sequencing of expenditure and

\footnotetext{
${ }^{2}$ These results underscore the need for further research, especially on the relative importance of the channels through which symmetric and non-symmetric commodity price shocks affect output.
} 
tax decisions to be statistically determined, contrary to the specification adopted by Blanchard and Perotti (1999). This paper extends the Blanchard-Perotti approach and tests for differences in responses to commodity price shocks across tax regimes, a distinction that was not made in Blanchard and Perotti.

\section{Dynamic effects of commodity price shocks}

Turning to the estimated impulse-response functions, we focus on the dynamic effects of identified commodity price shocks under both tax regimes. The response variables of interest are the revenue/GDP, expenditure/GDP, and fiscal balance/GDP ratios. All the simulations are performed by considering a 1 percent positive transitory shock to the commodity price index and its impact on the fiscal aggregates over 12 quarters following the shock. The results in Figure 2 are the estimated average dynamic responses for the oil-exporting countries (Kazakhstan and Russia) and the non-oilexporting commodity-intensive countries (the Kyrgyz Republic and Tajikistan).

The results indicate that, following a 1 percent positive shock to the oil price (in the case of the oil-exporting countries), revenues increase leading to budget surpluses. For the non-oil-exporting countries, the increase in the composite commodity price index leads to increases in revenues, expenditures, and the budget deficit. This latter result reflects the incremental cost of oil imports on the budget-increasing budget deficits, despite the increases in revenues in response to increases in the prices of their export commodities. The overall change in the fiscal balance for the two groups of countries seems more pronounced under the active tax regime than under the passive tax regime (that is, under Model I, where tax policy is assumed independent of, and in advance of, expenditure decisions). ${ }^{3}$ This finding is partly explained by rigidity of expenditures even as commodity price increases dissipate.

Output responses differ across fiscal regimes. When tax policy leads, and is independent of, expenditure decisions (as under the passive tax regime), output volatility is lower for both groups of countries than when expenditure decisions are made in anticipation of tax receipts (as under the active tax regime). Again, whereas the positive oil price shock increases output in the oil-exporting countries, the composite commodity price shocks in the nonoil-exporting countries reduce output because of the inclusion of oil prices in the composite index. An alternative specification of the commodity price index (where oil prices are excluded from the index) in the analysis on

\footnotetext{
${ }^{3}$ The average responses shown in Figure 2 blur the differences between responses across tax regimes. Country-specific responses, not reported in this paper, display more distinct variations across tax regimes. In Figure 2, the differences between responses across tax regimes are more pronounced for output than for the fiscal aggregates. Intuitively, this result is mainly due to the additional effects of changes in taxes and spending on output (through $\theta_{2}$ and $\theta_{3}$ in Equation (3)), following the commodity price shock.
} 
Figure 2. Tax Regimes and Responses to Commodity Price Shocks (In percent)
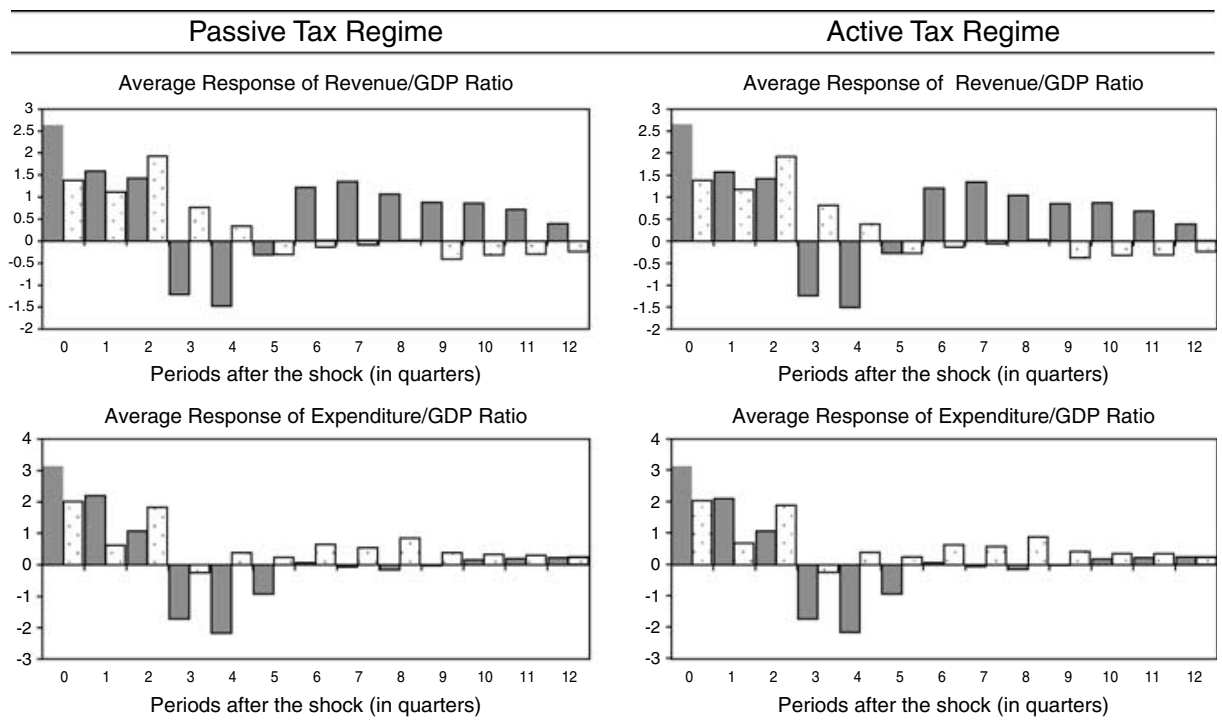

Average Response of Deficit/GDP Ratio

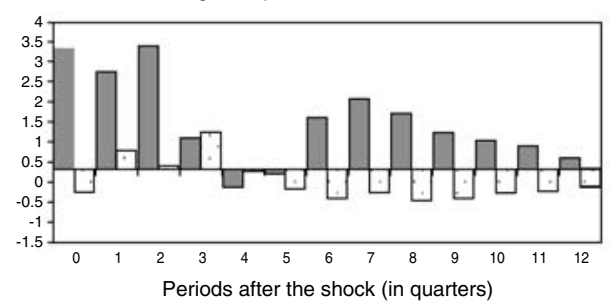

Average Response of Deficit/GDP Ratio
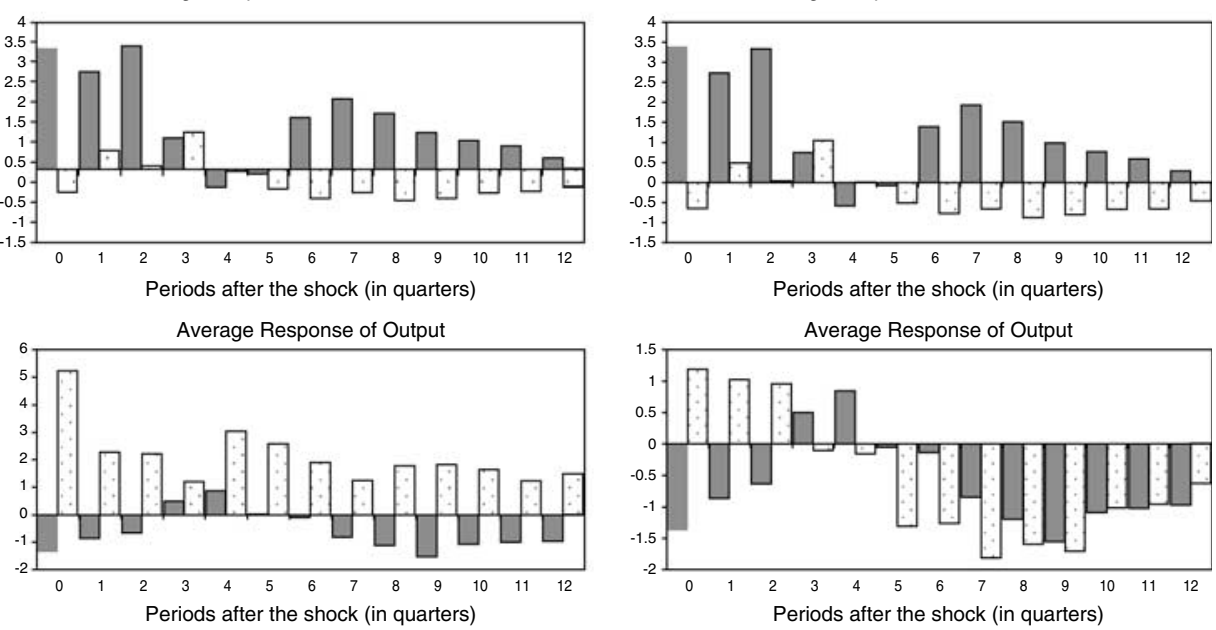

E Average responses for Kyrgyz Republic and Tajikistan

$\square$ Average responses for Kazakhstan and Russia

Source: Authors' estimates.

Notes: The charts reflect estimates of responses to a 1 percent increase in the composite commodity price index under alternative fiscal regimes - the passive tax regime (represented by results from Model I) and the active tax regime (represented by results from Model III).

Tajikistan and the Kyrgyz Republic yields an increase in output in response to a positive commodity price shock. Our untested hypothesis is that the decline in output in each of the two countries - the Kyrgyz Republic and Tajikistan_-varies with the degree of oil intensity in each country. Thus, oil 
price increases lead to output declines in non-oil-exporting countries in our sample, whereas oil-exporting countries reap gains in terms of output expansion.

Further inspection of country-specific impulse-response functions reveals broadly consistent responses among commodity-producing countries. Specifically, in response to a positive commodity price shock, we observe a rise in output during the first year of the shock. After approximately four quarters, the output response reaches its peak and reverts to its original level, and in the long run the effects of the positive commodity price shock on output tends to disappear.

\section{Forecast Error Variance Decomposition}

To assess the relative strength of shocks in explaining movements in fiscal aggregates (essentially, movements of revenues and expenditures), we consider forecast error variance decompositions under the two broad tax regimes. Consistent with our earlier results, the decompositions suggest that commodity prices have significant short- and long-term effects on variations in revenues. This impact is particularly strong for the oil-exporting countries. It is worth noting that oil price changes contribute significantly to revenue and expenditure variations over the forecast horizon. For instance, under the active tax regime, more than 20 percent of the forecast error in the fourth quarter is attributable to oil price changes. Aggregate supply shocks (measured as variations in output) have a lower impact on revenues and expenditures, especially in the short run. This result suggests that changes in revenues and spending are driven mostly by commodity price fluctuations and the fiscal policy stance, including the effectiveness of tax administration and budget execution.

\section{The Odds on Fiscal Performance}

The estimated model is used to generate stochastic simulations to assess the likelihood of exceeding fiscal floors and ceilings (in the case of the non-oilexporting commodity-intensive countries, the Kyrgyz Republic and Tajikistan) and of a worsening of the fiscal stance (in the case of the oilexporting countries, Kazakhstan and Russia) over the forecast horizon. Each stochastic simulation generates a hypothetical response path for the variables of the model following a positive shock to the commodity price index. These hypothetical paths are functions of two determinants - structural disturbances to the economy and the propagation mechanism of the economy, which are characterized by the specifications under each fiscal regime.

The structural VAR simulation procedure used in the paper is similar to that used by Dalsgaard and de Serres (1999). Unlike Dalsgaard and de Serres, who use Monte Carlo simulations, we adopt a bootstrapping approach with 2,000 replications of the estimated structural VAR (see 
Runkle (1987), for instance, for a description of this procedure) ${ }^{4}$ to simulate impulse responses ${ }^{5}$ that are further analyzed in determining (1) the dynamic behavior (in the forecast horizon) of revenues, expenditures, and fiscal balances at the $\alpha_{1}$-significance level and (2) the probability of exceeding specified revenue, expenditure, and deficit/surplus baseline or targetsfollowing a 1 percent commodity price shock. The simulations underlying the likely levels of the fiscal aggregates at a given significance level show fluctuations of these aggregates around their trend values in response to unexpected commodity price shocks.

The estimated structural VAR is simulated 2,000 times and cumulative distributions are derived for the estimated impulse responses under each tax regime over the forecast horizon, $k$. Figure 3 shows an example of probability distributions of the responses of the revenue/GDP ratio and the expenditure/ GDP ratio over the forecast horizon, following a 1 percent positive shock to the commodity price index - the responses of the fiscal balance are derived from these two. For illustrative purposes, the target/baseline revenue and expenditure ratios in Figure 3 are set at 5 percent. The lines $k=0, k=4$, $k=8$, and $k=12$ indicate the probability distribution of the fiscal ratios (revenue/GDP and/or expenditure/GDP) $k$-quarters after a 1 percent positive commodity price shock. For instance, the $k=0$ line in the revenue panel indicates that the probability of exceeding the revenue baseline following a positive 1 percent commodity price shock is about 90 percent (that is, 100 minus 10 percent). A corresponding estimate of the probability of exceeding the expenditure baseline or ceiling at the zero horizon (that is, along line $k=0)$ is 80 percent (that is, 100 minus 20 percent). The various $k$-lines indicate, therefore, the probabilities of exceeding fiscal floors or ceilings (or baseline fiscal ratios) at various horizons following the positive price shock. The figure also shows the likely levels of the fiscal aggregates at the $\alpha_{1}$ significance level at each horizon. These levels are given by the points of intersection between the vertical line labeled "5 percent significance level" and the estimated probabilities at each forecast horizon $(k)$. The figure suggests, for instance, that at the 5 percent significance level, the revenue ratio is likely to be above 5 percent of GDP for all $k$-quarterly forecast periods following a 1 percent positive commodity price shock. This approach

\footnotetext{
${ }^{4}$ The approach enables inferences on the likelihood of estimated responses exceeding some predetermined levels - this yields the probabilities that we discuss in the next section. We also infer the level of the responses at any given (say, $\alpha_{1}$ ) significance level, yielding the expression " $\alpha_{1}$-significance level" of these responses.

${ }^{5}$ This approach is widely used in the structural VAR literature to estimate confidence bands for simulated impulse responses. It assumes, however, that the impulse responses are independently distributed through time, which in a strict econometric sense is not precise. Hence, the confidence bands should not be interpreted as the usual confidence intervals, but rather as indications of uncertainty around parameter estimates. This is precisely how we use the simulated bands in this paper - to derive probabilities of exceeding fiscal targets and the $\alpha_{1}$-significance levels of the relevant fiscal variables.
} 
Figure 3. Illustrative Probability Distribution of Fiscal Aggregates
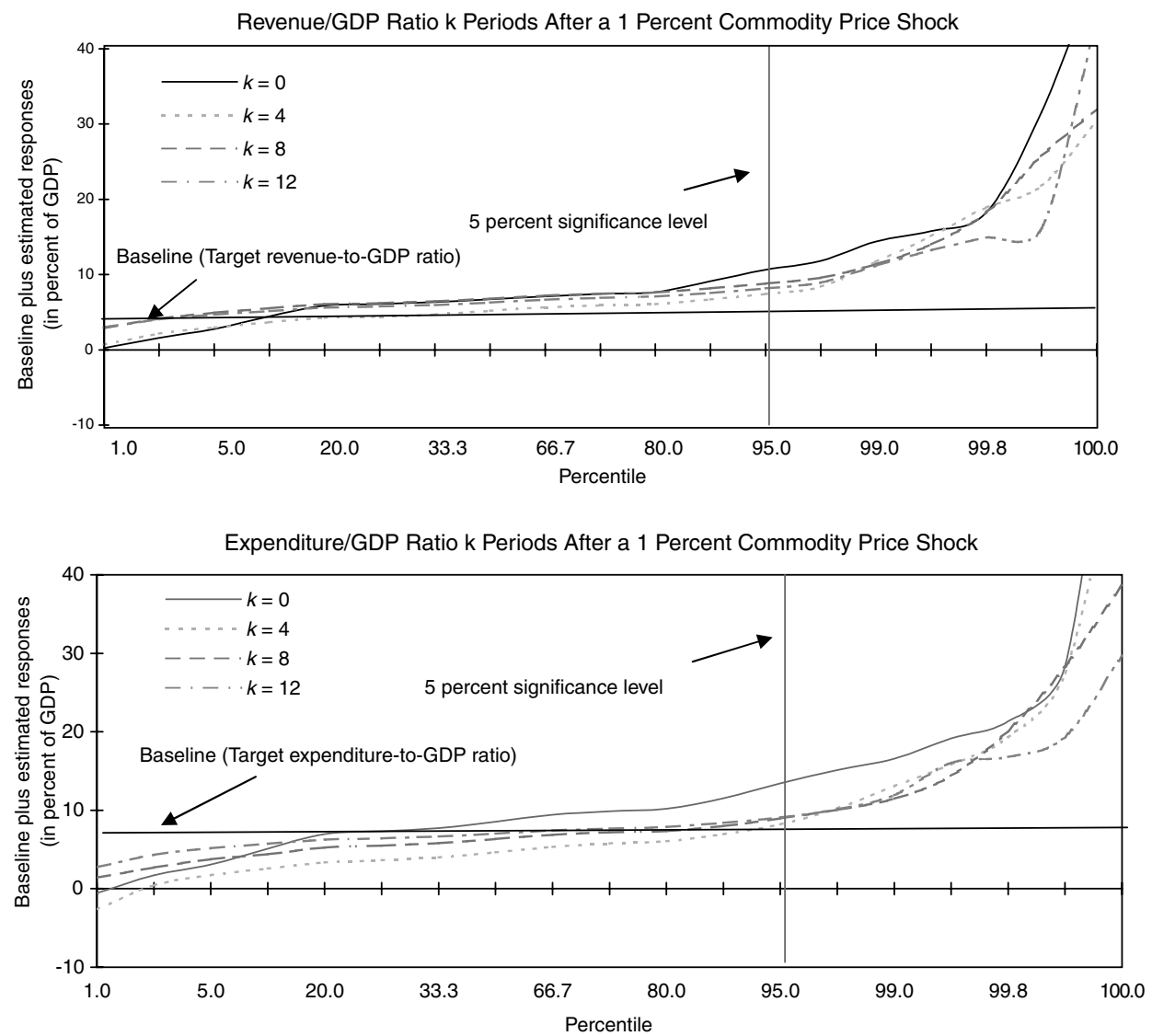

Source: Authors' simulations, based on estimated structural VAR model.

is used to estimate the $\alpha_{1}$-significance level of fiscal aggregates and probabilities of fiscal overperformance relative to the baseline or target.

\section{Fiscal aggregates at $\alpha_{1}$-significance levels}

The first characterization of the responses of the fiscal aggregates to commodity price shocks shows how the tax and expenditure aggregates will fluctuate around their trend values in response to a positive unexpected transitory commodity price shock. The simulations provide, therefore, a basis for determining the size of the buffer required to protect against unexpected shocks driving these fiscal aggregates outside a specified band. Average simulation results for the two sets of countries are presented in Figures 4 and 5. Again, Model I and Model III represent the passive and the active tax regimes, respectively. The first set of simulations searches for the upper bound for the fiscal aggregates at a given confidence level (in this case, at the 5 percent level), within the context of a positive commodity price shock. 
Model I- Passive Tax Regime

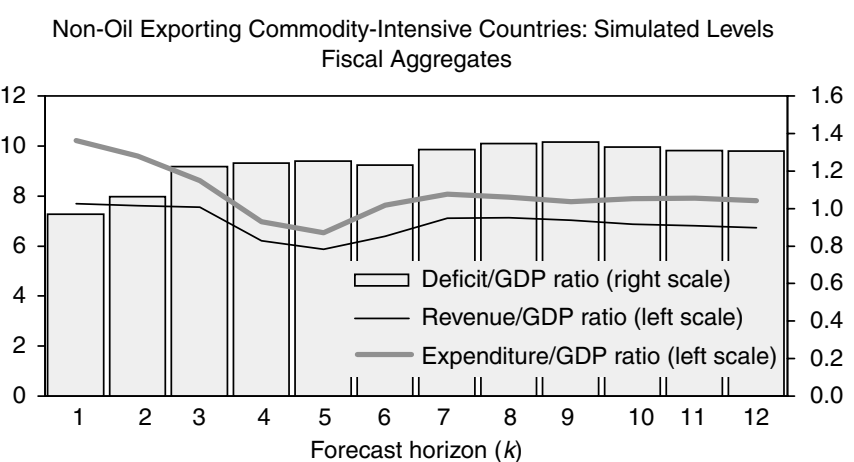

Oil-Exporting Countries:

Simulated Levels of Fiscal Aggregates

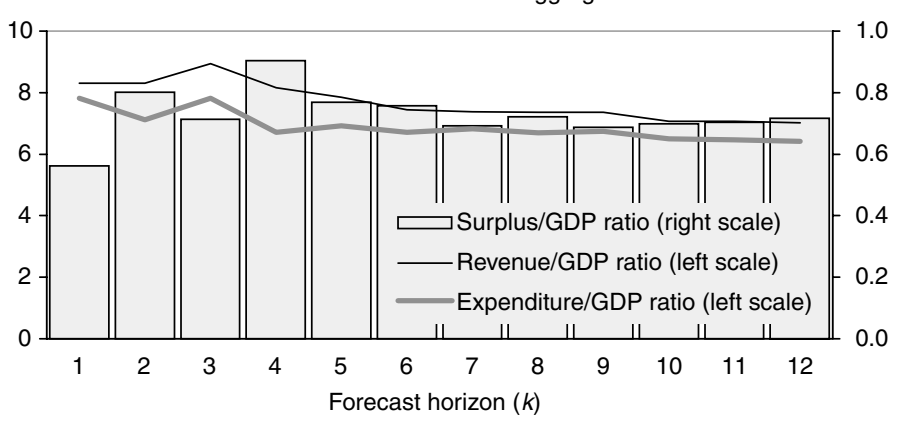

Model III- Active Tax Regime

Non-Oil Exporting Commodity-Intensive Countries: Simulated Levels Fiscal Aggregates

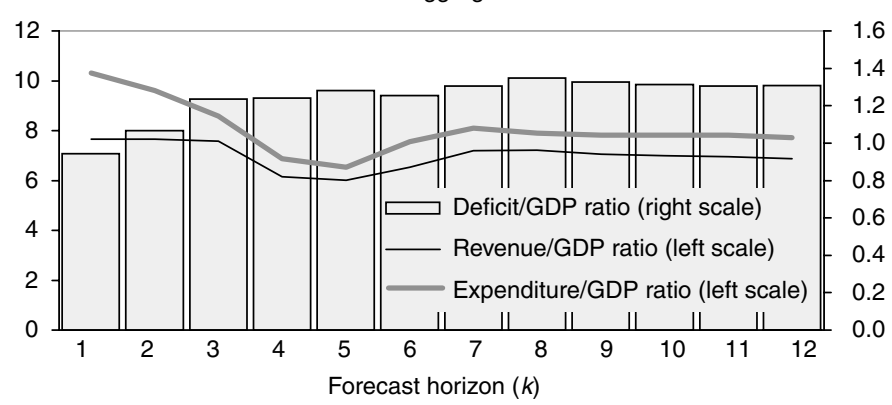

Oil-Exporting Countries:

Simulated Levels of Fiscal Aggregates

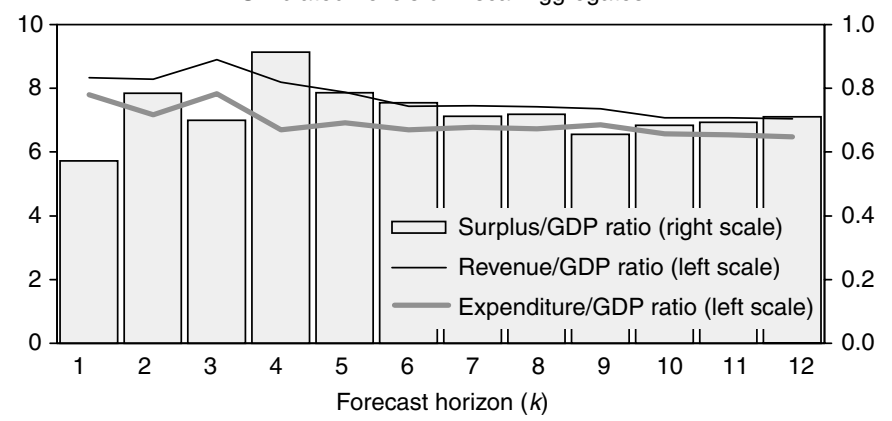

Source: Authors' simulations, based on estimated impulse-response functions. 
Figure 5. Tax Regimes and Average Probabilities of Exceeding Prespecified Fiscal Ratios (In percent)

Non-Oil Exporting Commodity-Intensive Countries (Kyrgyz Republic and Tajikistan)

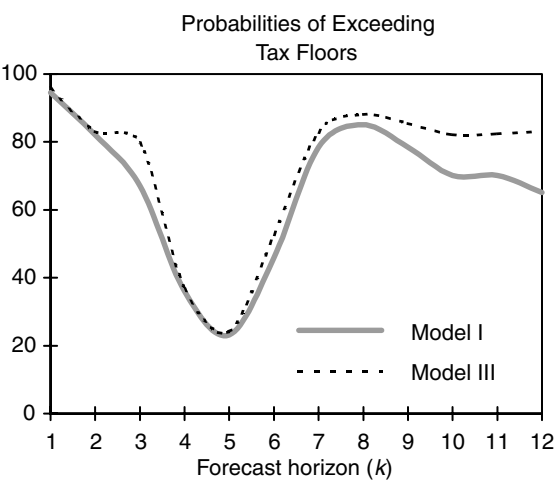

Probabilities of Exceeding
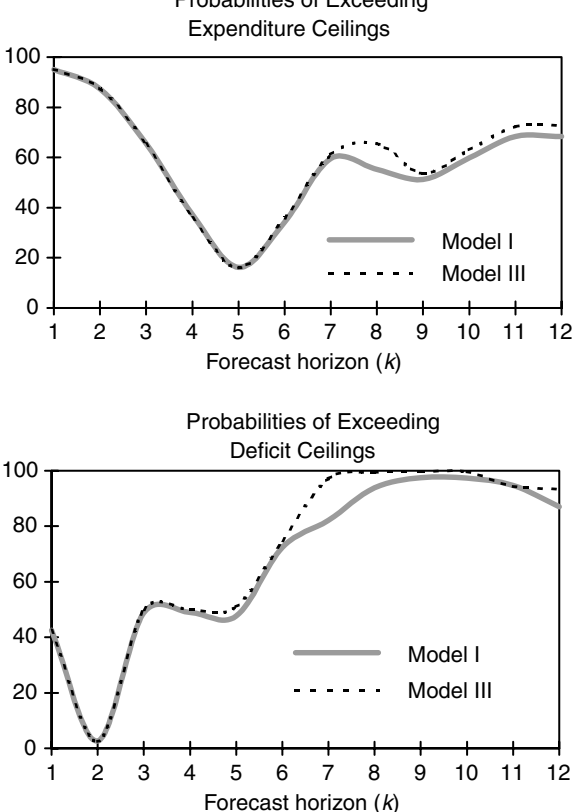

Oil-Exporting Countries

(Kazakhstan and Russia)

Probabilities of Exceeding Tax Floors

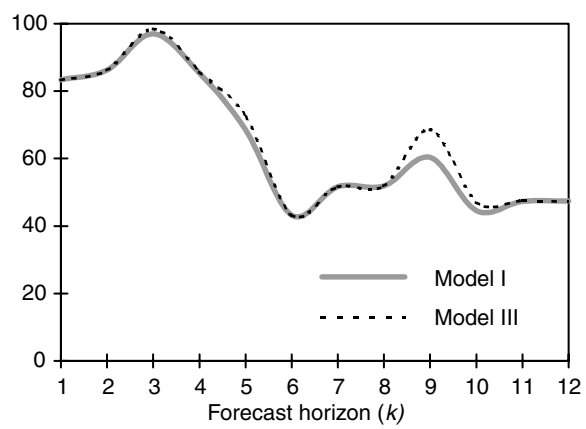

Probabilities of Exceeding

Expenditure Ceilings

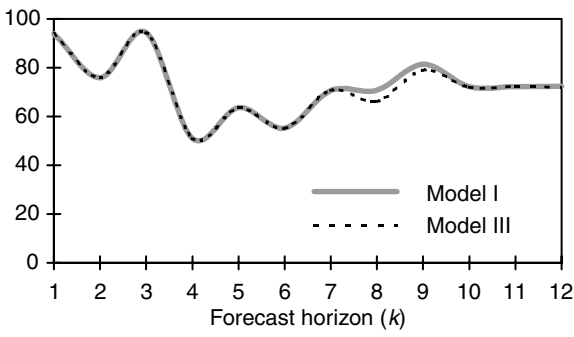

Probabilities of Exceeding

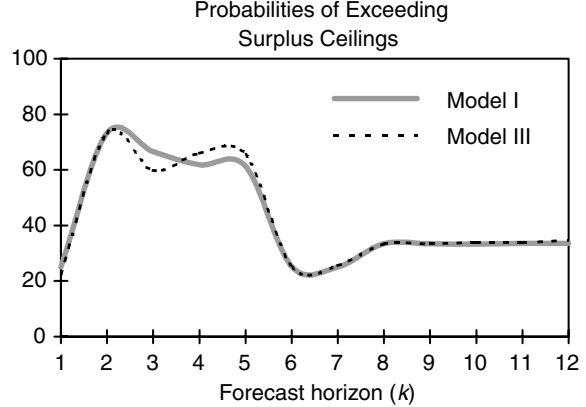

Source: Authors' bootstrapping simulations, based on estimated impulse-response functions.

The results vary across the countries in our sample, reflecting institutional differences, and across models. Generally, the results for the oil-exporting countries indicate higher revenue at the 5 percent significance level than expenditures over the forecast horizon, following a 1 percent oil price shock-resulting in higher fiscal surpluses, particularly in the short run (Figure 4). For the non-oil-exporting commodity-intensive countries, however, the simulations point to higher levels of expenditures than revenues. Thus, the simulations point to increases in fiscal surpluses (an 
improvement in fiscal performance) in the oil-exporting countries and an increase in the deficits (a worsening in fiscal performance) in the non-oilexporting ones, following the commodity price shock. This is because expenditures increase in the latter group of countries following the commodity price increase, although tax administration may not be strong and flexible enough to capture the potential tax yield from higher commodity prices. Country-specific results described in Kumah and Matovu (2005) reveal more details.

Further, the simulations suggest a higher likelihood of exceeding fiscal floors and ceilings during the short term when prices are high. However, after the transitory shock has dissipated, these probabilities decline significantly. Understandably, the levels of the fiscal aggregates suggested by the simulations may differ from projections that take into account additional considerations, such as the need for faster fiscal adjustment to support debt sustainability and to foster private sector-led growth (as in the cases of Tajikistan and the Kyrgyz Republic) or the need to use the oil revenues to speed up reforms (as in the cases of Russia and Kazakhstan).

\section{Probability of exceeding fiscal floors and ceilings}

The second set of simulations estimates probabilities of exceeding fiscal floors and ceilings (in the cases of the non-oil-exporting commodity-intensive countries, the Kyrgyz Republic and Tajikistan) or performing worse than the recent trend (in the cases of the oil-exporting countries, Kazakhstan and Russia). These probabilities are conditional on the estimated responses to a 1 percent positive shock to the commodity price index. A priori, one would expect the probability of overperforming revenue floors to be higher under the active tax regime than under the passive regime, because the former regime benefits from an additional revenue boost from expenditure increases. The simulation results confirm this belief, but this particular sequencing of tax and expenditure policy - the active tax regime - does not necessarily yield higher/lower likelihoods of exceeding fiscal surpluses/deficits, because it is also generally associated with higher expenditures than under the passive tax regime (Figure 5).

In general, fiscal floors and ceilings are easily exceeded during the first year of the positive commodity price shock. However, this performance deteriorates shortly after the transitory shock. In the long run, the active tax regime yields higher probabilities of exceeding deficit ceilings, especially in the cases of the non-oil-exporting commodity-intensive countries (the Kyrgyz Republic and Tajikistan). This is mainly because expenditures that get entrenched during the commodity price boom periods are adjusted slowly once the commodity price declines. The results for the oil-exporting countries do not show significant differences between the two tax regimes, although they indicate long-term deterioration of the fiscal stance. This result reflects the fact that the probability of exceeding the prespecified expenditure ceiling rises faster than that of exceeding the revenue floor, leading to a decline in the probability of exceeding the fiscal surplus, particularly under the active tax regime. 


\section{Concluding Remarks}

This paper estimated a standard structural VAR model, identified two broad tax regimes, and carried out simulations that generated likely levels of relevant fiscal aggregates at the 5 percent significance level and probabilities of exceeding fiscal floors and ceilings in the context of volatile commodity prices. The lessons from the simulations suggest that sequencing of expenditure and tax policies is crucial for fiscal performance. Thus, within the context of uncertain commodity prices, countries have higher probabilities of meeting fiscal targets if they follow a more conservative tax regime - a passive tax regime - rather than allowing revenue targets to be determined by expenditure commitments. For the oil-producing countries, expenditure restraint will be beneficial when rising oil prices are transitory, as in the case analyzed in this paper, because the probability of overperforming recent trends in fiscal surpluses declines once the revenueenhancing effects of the transitory oil price increase dissipate.

In addition to adopting a conservative tax regime even in the context of increasing commodity prices, increasing diversification of the economy will help enhance resilience (of non-oil-exporting commodity-intensive small economies, in particular) to commodity price shocks. Increasing dependence of fiscal revenues on commodity prices renders public finances vulnerable to a volatile external variable that is, for the most part, largely beyond the control of policymakers. This calls for further diversifying the economy by eliminating bottlenecks to private sector development to bolster the resilience of the economy to external shocks including commodity price shocks. The high volatility of commodity prices also calls for flexibility in the design and application of medium-term budget frameworks in commodity-intensive economies.

\section{APPENDIX}

\section{Data Description, Sources, and Time Series Characteristics}

In estimating the reduced-form VAR for each of the countries in the sample, we use the logarithm of seasonally adjusted quarterly data on a composite commodity price index $\left(P \operatorname{com}_{t}\right)$, relevant fiscal variables - the revenue/GDP ratio $\left(\operatorname{Rev}_{t} / y_{t}\right)$ and the expenditure/GDP ratio $\left(\operatorname{Exp}_{t} / y_{t}\right)$-and output $\left(y_{t}\right)$. These variables form the data set $\left\{X_{t}: X_{t}=\left[\ln \operatorname{Pcom}_{t}, \ln \left(\operatorname{Rev}_{t} / y_{t}\right), \ln \left(\operatorname{Exp}_{t} / y_{t}\right), \ln y_{t}\right]^{\prime}\right\}$. The composite commodity price index for the oil-exporting countries in our sample (Kazakhstan and Russia) coincides with the oil price index because their main export product is oil. For the non-oil-exporting commodity-dependent countries, however, we use the weighted average of the oil price index and the price indices of the main export commodities of each country - gold for the Kyrgyz Republic and cotton and aluminum for Tajikistan. ${ }^{6}$ The weights are derived as the 2004 shares of these commodities in the total trade of each country. The revenue variable used in this paper includes tax and

\footnotetext{
${ }^{6}$ In line with the focus of the paper, we include the price of oil in the index to capture the direct impact of changes in these prices on tax receipts - and indirectly through the oil price elasticity of output.
} 
nontax revenues, the expenditure variable comprises current and capital spending, and output refers to nominal GDP.

The sample periods differ for each of the countries, reflecting data availability. The sample covers 1995:Q1-2004:Q4 for the Kyrgyz Republic, 1996:Q1-2004:Q4 for Tajikistan, 1994:Q1-2004:Q2 for Kazakhstan, and 1994:Q2-2004:Q2 for Russia. Data on output, total revenues, and expenditures are obtained from International Monetary Fund data sources complemented with data reported by the authorities. Oil, aluminum, gold, and cotton prices are downloaded from Datastream.

Detailed analysis of the time series characteristics of the data (presented in Kumah and Matovu, 2005) indicates that, generally, the logarithms of commodity price indices and the output series follow unit root processes with possible drift, whereas the revenue/GDP and expenditure/GDP ratios (except in the case of Russia) follow stationary processes - that is, they are integrated by degree zero. Further, a check for co-integration using the Johansen approach reveals that the data set for all the countries have four co-integrating vectors. We therefore estimated the reducedform VARs using the logarithm levels of the variables, choosing the lag lengths to ensure invertibility of the system and well-behaved error terms.

\section{REFERENCES}

Barnett, S., and R. Ossowski, 2002, "Operational Aspects of Fiscal Policy in Oil-producing Countries," IMF Working Paper 02/177 (Washington, International Monetary Fund).

Blanchard, O., and R. Perotti, 1999, "An Empirical Characterization of the Dynamic Effects of Changes in Government Spending and Taxes on Output," NBER Working Paper No. 7269 (Cambridge, Massachusetts, National Bureau of Economic Research).

Dalsgaard, T., and A.de Serres, 1999, "Estimating Prudent Budgetary Margins for 11 EU Countries-A Simulated SVAR Model Approach," OECD Working Paper No. 216 (Paris, Organization for Economic Cooperation and Development).

Engel, E., and R. Valdés, 2000, "Optimal Fiscal Strategy for Oil Exporting Countries," IMF Working Paper 00/118 (Washington, International Monetary Fund).

Fatás, A., and I. Mihov, 2001, "Government Size and Automatic Stabilizers: International and Intranational Evidence," Journal of International Economics, Vol. 55 (October), pp. 3-28.

Jiménez-Rodríguez, R., and M. Sánchez, 2004, "'Oil Price shocks and Real GDP Growth: Empirical Evidence for Some OECD Countries,” ECB Working Paper No. 362 (Frankfurt, European Central Bank).

Kumah, F.Y., and J.M. Matovu, 2005, "Commodity Price Shocks and the Odds on Fiscal Performance," IMF Working Paper 05/171 (Washington, International Monetary Fund).

Perotti, R., 2002, "Estimating the Effects of Fiscal Policy in OECD Countries," ECB Working Paper No. 168 (Frankfurt, European Central Bank).

Runkle, D., 1987, "Vector Autoregressions and Reality," Journal of Business and Economic Statistics, Vol. 5 (October), pp. 437-442. 